\title{
CONVERSION, PIETY AND LOYALISM IN ANCIENT EGYPT
}

\author{
Jan Assmann
}

In those texts from the New Kingdom which we usually associate with the phenomenon called "Personal Piety", we meet with a rather emphatic rhetoric of polarity and decision. The most characteristic element of this rhetoric is a form which we may call "makarismos" (béatitude) following the terminology of Biblical and Classical scholars. It consists of opposing two antithetic attitudes towards god and giving praise to the one and woe to the other. Let me quote just one typical example:

I will give praise to your beautiful face, and propitiate your Ka daily, for I have placed myself upon your water and have filled my heart with you.

You are a god to whom one can appeal, gentle of heart towards mankind.

Happy the man who puts you into his heart, woe to him who attacks you!

Because of your wrath being so great, because of your plans being so efficient, because of your mercy being so fast. ${ }^{1}$

There are several dozen examples which I have collected in an earlier article. ${ }^{2}$ We may safely assume that the form of makarismos is very typical of the general trend or movement of Personal Piety. Not all of the examples are antithetic like the one just quoted. Many consist only in a praise of the pious one without mentioning the opposite case. However, the general presupposition seems to be that there are two possible forms of a relationship between god and man,

${ }^{1}$ Cube statue of Ramose, see F.R. Herbin, Histoire du Fayum de la xviii.e à la xxx.e dynastie (thèse du III.e cycle, Sorbonne Paris 1980), 187 doc. 189. I owe this to Pascal Vernus.

2 "Weisheit, Loyalismus und Frömmigkeit", in: E. Hornung, O. Keel (Hrsg.), Studien zu altägyptischen Lebenslehren (Orbis Biblicus et Orient. 28), Fribourg und Göttingen 1979, 11-72. 
piety and impiety, and that a human being is in the situation of deciding which way to go, which attitude towards god to adopt, which relationship to form. Therefore, piety seems to have been conceived of as a form of relationship between man and god based on a conscious decision. Piety is not something natural, innate and inevitable such as Schleiermacher's "Kreaturgefühl" (the innate feeling of being a creature of god), but a relation which has to be consciously and conscientiously chosen and formed.

Other texts are a little more explicit concerning the antagonistic attitudes of piety and impiety. Two famous texts oppose the "silent one" and the "heated one". It seems evident that this opposition refers to the same pair as the inscription just quoted which opposed the pious one "who placed god into his heart" and the impious one "who attacks god".

O Thot, you well that is sweet

to a man who thirsts in the desert!

It is sealed to him who finds words.

It is open to the silent.

Comes the silent, he finds the well.

To the heated man you are hidden. ${ }^{3}$

As for the heated man in the temple, he is like a tree growing indoors.

A moment lasts its growth of shoots, Its end comes about in the woodshed. It is floated far from its place, the flame is its burial shroud.

The truly silent, who keeps apart, $\mathrm{He}$ is like a tree grown in a meadow. It greens, it doubles its yield, it stands in front of its lord. Its fruit is sweet, its shade delightful, Its end comes in the garden. ${ }^{4}$

${ }^{3}$ Gardiner, LEM, 85f.; Caminos, LEM, 321; Lichtheim, AEL II, 114.

${ }^{4}$ Amenemope VI.1ff. chapter IV; Lichtheim, AEL II, 150f. I. Shirun-Grumach, "Die Lehre des Amenemope", in: O. Kaiser (Hrsg.), TUAT III.2, Weisheitstexte II, Gütersloh 1991, 230. Grumach; R. Anthes, in: A. Kuschke/E. Kutsch (Hg.), Archäologie und Altes Testament (Fs. Kurt Galling), Tübingen 1970, 9-18; G. Posener, ZÄS 99, 1973, 129-135; Sh. Israeli, "Chapter Four of the Wisdom Book of Amenemope", in: Studies in Egyptology (Fs. M. Lichtheim), Jerusalem 1990, I, 464-484. 
Putting god into one's heart means trust in god and abstinence from heated action. The pious one gives up the heat of will and passion and adopts a quietistic attitude. It is interesting to consider this phenomenon in the context of conversion. Of course, we are not dealing here with "conversion" in the full sense of the term, such as it has been defined and phenomenologically demonstrated by Arthur Darby Nock more than 60 years ago. Conversion in the proper sense is inseparably linked to a notion of absolute and metaphysical truth that is alien to ancient Egypt. We have to wait for another thousand years until this idea of superior truth becomes socially influential, that is, until communities emerge that gather around such a truth. Conversion in the full sense of the term means to enter such a community after having recognized the superiority of its truth.

There are no communities of this kind in ancient Egypt, no doctrine or conceptual framework to adopt by "converting" to such a community and its superior truth. The only element which seems comparable to the phenomenology of conversion is the element of decision. Whether this decision for god implies certain theological or metaphysical doctrines and certain ethical principles we cannot know. However, there are certain texts that shed at least some light on the question as to what it could have meant to have made the decision or, to use the Egyptian term, to put god in one's heart and to act on the water of god.

I propose to first have a look at these texts, then to ask for the history of this concept and the conditions of its origin and development and lastly to (at least tentatively) draw some conclusions concerning our general question of the concept of person and its transformations in the ancient world.

An ostracon from the time of Ramses II. has preserved a literary text which reads like the confession of somebody who has made the decision for god:

I have put yesterday and today in the hands of Amun and was found safe and my plans firmly established.

I made for myself a beautiful remaining until my time is fulfilled, rendering myself over to him completely; he is my mooring post. 
O what happiness is a burial, there is nothing like it.

A protector among men vanishes, his plans fail.

I gave myself to Amun and I found what is good. ${ }^{5}$

The content of this strange confession becomes much clearer when compared to an inscription in the tomb of a certain Zimut-Kiki at Thebes from the same time. ${ }^{6}$ In this inscription, Kiki renders account of his decision for the goddess Mut and its economical implications.

There was a man of Southern On,

a true scribe in Thebes;

Zimut was the name his mother gave him, called Kiki, justified.

Him his god had instructed and made knowledgeable in his teaching; he put him on the way of life in order to preserve his limbs; god had recognized him already as a child and had assigned him food and riches.

Then he reflected upon himself to find for himself a protector. And he found Mut on top of the deities, fate and fulfilment in her grasp, life-time and breath at her disposal.

All that happens occurs upon her order.

He said: I will give her all my fortune and my income, for I recognize her power with my eyes, her unique efficiency.

She made my fear vanish and gave me shelter in the moment of distress.

She came, the north-wind ahead of her, when I called her by her name.

I am a weak one of her town,

a poor one and a pilgrim of her city.

I disposed of my possession in her favor, in exchange for the breath of life.

No one of my household shall have a share in this, but to her Ka shall belong everything in peace. (...)

Colin Campbell 4 (Glasgow D.1925.69), ed. J. Černý and A.H. Gardiner, Hieratic Ostraca, Oxford 1957, pl. 39.1; ÄHG Nr. 186; TUAT 23.

${ }^{6}$ Abd el Qader-Mohammad, in: ASAE 59, 1960, pl. 48ff.; J.A. Wilson, in: JNES 29, 187-92; ÄHG Nr. 173. Pascal Vernus, "Littérature et autobiographie. Les inscriptions de S3-Mwt surnommé Kyky", in: RdE 30, 1978, 115-146. 
I did not choose for myself a protector among humans,

I did not attach myself to the mighty one.

There is no son of me that I found out in order to arrange my burial.

The burial is in your hand alone, you are the goddess of birth who will provide for me with a perfect mummy when the time of dying will have come. I have assigned to you all my possessions, you have entered into all my property.

Therefore you may now provide for my protection from all evil until my end has come!

Let my eyes see the rays of the female sun,

let my ears hear without deafness, my nose breathe the air, the way (sic) of life enter my body without interruption, let my neck and my throat breathe, let my mouth be efficient and my lips sharp, let my tongue distinguish the taste, all my members being complete and alive.

There is no claim on my body, no tongue has power over me, no human being shall hurt me.

The text continues in the same vein for about another 50 verses but I will stop here because the argument has by now become clear. We are dealing not only with an act of conversion but also with an economical transaction. Kiki has transferred his property to the temple of Mut in exchange for a kind of insurance both for his lifetime and for his burial and mortuary cult. Another inscription in his tomb gives a copy of the official document of transaction. He calls this "making Mut his protector" or "patron" and explicitly states to have preferred Mut to a human patron and to a member of his own family. We are now in a position to better understand the first text which also speaks of rendering oneself over to Amun, mentions in this context the burial and calls Amun a mooring-post. The author of this text or rather the "I" in whose mouth the speech is put has made the same decision as Kiki did. He chose Amun as a protector to provide for his life and burial.

It seems quite evident that Kiki had deliberately chosen Mut in a situation of choice and decision. He explains his decision for Mut by hinting to an experience of salvation in times of anxiety. In another stanza he says: 
My heart is filled with my mistress.

I have no fear of anyone.

I spend the night in quiet sleep,

because I have a protector.

Already some 150 years earlier we read on an ostracon:

I gave you into my heart because of your strength. [...]

You are my protector. Behold: my fear has vanished. ${ }^{7}$

These sentences were scribbled on a chip of limestone and placed before the god on the occasion of a festive procession. They seem to attest an experience similar to that of Kiki and perhaps even a similar decision which must not necessarily have implied similar economical transactions. So much is clear that in all these cases the decision refers to the choice of a protector or patron. Another example comes from a literary text of the Ramesside period:

Pilot who knows the water,

Amun, steering-oar that does not lead astray!

Who gives bread to him who has none,

who keeps alive the servant of his house.

I did not choose for myself a magistrate as protector,

I did not attach myself to a rich one,

I do not give my share to a man who was in the house of [the king].

My lord is my protector!

I know his strength.

$\mathrm{He}$ is a protector with powerful arm, he alone is strong. ${ }^{8}$

Decision is a reaction. It is a step that one is forced to take when confronted with an alternative, a binary situation. In our case, this binary situation appears in a personalized form. You are summoned to make a decision for or against god. You are confronted with a will and a claim and you are free to follow or to resist this will. It is this will or claim that structures reality in a binary way. "Who is not for me is against me." The strongest analogies to this situation

${ }^{7}$ Cairo CG 12217 recto ed. G. Posener, in: "La piéte personelle avant l'age amarnien", Revue d'Egyptologie 27, 1975, 206f.

${ }^{8}$ Anastasi II, 9.2-10.1; Gardiner, 17f.; Caminos, 58f.; ÄHG 177. 
are to found in the realm of politics. Carl Schmitt who was a fascist and an anti-semite and thus not an authority to be quoted with ease nevertheless had a point in holding that the realm of the political is structured by and based upon the distinction between friend and foe and that it is this decision which has to be recognized as the fundamentally political one. According to Schmitt, the political space is constructed by making the distinction between pro and con, friend and enemy. The rhetoric of decision is based on a politics of polarization. The claim of god to form a decision is a political claim. In claiming or at least implying the principle "Who is not for me is against me", God is acting as a politician, as a sovereign lord. With the category of decision, we are entering the realm of political theology.

This interpretation is overwhelmingly confirmed by texts dealing with the king instead of god. These texts, which belong to the Middle Kingdom and are thus much older than the New Kingdom texts of Personal Piety, prove to be the proper place of a rhetoric of decision and are to be considered without any doubt as the model of the New Kingdom concept.

In a text called the Loyalist Instruction we read (and I give only a small selection out of a wealth of similar antithetic formulations):

He whom he favours will be a possessor of nourishment, but he who defies him will have nothing. ${ }^{9}$

He who is loyal to the king will be a possessor of a tomb, but no tomb for him who rebels against His Majesty. ${ }^{10}$

The king is Bastet who guards the Two lands, he who worships him is protected by his arm.

He is Sakhmet to him who defies his command, he whom he hates will become homeless. ${ }^{11}$

These quotations come from a literary text and a work of propaganda, addressed to the noble families in order to win them over for the cause of the ruling dynasty. This 12 th dynasty was in a peculiar situation. It was confronted with the task of liquidating the anarchy or rather "polyarchy" of the First Intermediate Period and of

${ }^{9}$ Loyalist Instruction ed. G. Posener, L'Enseignement loyaliste. Sagesse égyptienne du Moyen Empire, Genf 1976, 22, 76-77, § 3.9-10, Papyrusfassung.

${ }_{10}^{10}$ Posener, a.a.O., 29-30, 92-93, § 6.3-4, Stelenfassung.

11 Posener, a.a.O., 26-29, 90-91, § 5.11-14. 
re-erecting a strongly centralized pharaonic monarchy. Feudalist structures had to be replaced by bureaucratic ones. The aristocracy saw itself placed before the decision either to enter the bureaucracy, to adopt the new-old political system and an attitude of loyal adherence to the dynasty, or to insist on its feudal power and to resist the claim for re-integration and subordination. The rulers of the 12th dynasty were weak - or clever - enough not to use force but rhetoric in building their empire. In this context, the rhetoric of decision and its semantics of polarization had a very concrete reference to social groups and historical situations.

However, the kings of the 12th dynasty were by no means the first ones to invent, use and develop this polarizing semantics. They inherited this tradition from the very system which they opposed. After the fall of the Old Kingdom, new social structures arose which can be characterized as "patron-client-relations". The break-down of the economic system of central redistribution necessitated the emergence of private enterprise on a local scale. Local lords, "big men" arose who based their claim of leadership on a clientele of adherents. This is the historical context in which the rhetoric of decision and its value-system of trust, loyalty, devotion, solidarity, obedience, protection etc. originated. For an example, let me quote some passages from the tomb inscriptions of a certain Ankhtifi of Mo'alla who appears as the most outspoken and the most characteristic figure among these big men of the FIP.

As to everyone on whom I placed my hand, no misfortune ever befell him, Because my heart was sealed and my counsel excellent.

But as to any fool and wretch who stands up in opposition, He receives according to what he gave.

Woe! will be said of one who is accused by me.

His board will take water like a boat.

For I am a champion without peer! ${ }^{12}$

The relation of a client to his patron is without any doubt a matter of decision. He is not born into this relation but enters it by (more or less) free choice among conflicting and rivalling claims for adherence. His motive for giving up independence and entering a

${ }^{12}$ Nach W. Schenkel, Memphis, Herakleopolis, Theben - die epigraphischen Zeugnisse der 7.-11. Dynastie Ägyptens, ÄgAbh 12, Wiesbaden 1965, 46f. Lichtheim, AEL I, 86. 
relationship of dependence is need of security and provision. He who adheres and proves loyal to the right patron will be secure: "No misfortune will ever befall him" as the frequently attested formula has it. ${ }^{13}$ From the point of view of the patron, society is divided into loyals and rebels, followers and ignorants. Their claim for adherents presents the world in a rather pessimistic light. For the ordinary people, future has only misfortune in store and it is only the patron who can provide an efficient protection against these misfortunes. This is the reason why both the inscriptions of the FIP and the didactic literature of the MK abound in descriptions of chaos. They need the concepts of danger, insecurity and chaos in order to create the political realm, the space of decision and their system of loyalistic values. In another inscription of the tomb of Ankhtifi we read:

As to him who listened to my counsel

no misfortune ever befell him.

Who listened to me praised god.

But he who did not listen to me said "Woe!"

For I am the protector of the fearful one,

the fortified place of him who fled from afar.

I am a champion without peer. ${ }^{14}$

The text could not be more explicit as to the polarization of reality and society which forms the principle of loyalism. Fortune and misfortune of an individual depend on his decision for or against a patron, for or against obedience. He who has made the decision for the patron and proves trustworthy is on the safe side and no misfortune will befall him. But woe to him who ignores his claim; he will have reason for regret and repentance. The principle of loyalism polarizes society into friends and foes. This is so because of the non-natural character of the patron-client-relationship. The submission to a patron is not without alternatives. There are other patrons and there is the possibility to keep independence. Therefore there is room for choice and decision, for loyalty and apostasy.

Where there is room for choice and decision, there are also favorable conditions for new and more individualized concepts of the person to emerge. This is quite evident both on the level of the patrons and on the level of the clients.

${ }^{13}$ W. Schenkel, "Nie kam ein Mißgeschick über mich", in: ZÄS 91, 1964, 137-38.

${ }^{14}$ Schenkel, a.a.O., 55. 
As to the patrons, they present themselves in their tomb-inscriptions as veritable Renaissance men. These inscriptions rejoice in the newly acquired possibilities of personal initiative. For almost a millennium, pharaoh had ruled the country as the sole source of planning, decision and action and the whole staff of officials and magistrates were reduced to mere tools and implements of the royal will. Now, after the collapse of this institution of centralized initiative, people discovered their individual possibilities of organizing local systems of political and economic administration.

The pharaohs of the 12th dynasty adopted this ideology and rhetoric because they were still operating in a space where there were alternatives to the monocratic system. At the beginning of the 2nd millennium B.c.E., the historical situation was still a situation of decision. Pharaoh had to present himself to his people as the most powerful patron of all, as "the good shepherd" to use the favorite metaphor of royal ideology. The role of the patron is unfolded in a great variety of metaphors. Beside the good shepherd we find images such as the pilot, the steering oar, the father of the orphan, the husband of the widow, all of which will reappear, along with some new ones, in the discourse of personal piety. There is a very obvious line of tradition, leading from the patrons of the FIP to royal ideology and from there to the theology of Personal Piety.

The clients are even more interesting in the context of our present study. They discover and develop a system of inner virtues and values and a concept of inner self or personality which is the seat of these virtues. The patron-client-relationship requires the inner self and its virtues because of the artificial character of this relationship. In contrast to "natural" relations such as family-relations and even the traditional concept of subject-king-relationship (which was considered to be something naturally and alternativelessly given), the client enters the relationship with a patron deliberately. This leads to a new emphasis on the inner self as the agency of deliberation and decision. Moreover, the client-patron-relationship can be revoked whereas relations of kinship and pharaonic subordination count as irrevokable. This leads to the invention of loyalty or fidelity as political virtues. Where there is no possibility of apostasy, there is no point in preaching loyalty. Loyalty is very much a matter of the inner self. It is not an outward relation but an inner attachment. The Egyptian word for what we have called inner self is "heart". In striking contrast to Old Kingdom phraseology where the heart 
plays no role at all, the heart becomes the central topic in the tombinscriptions since the Early Middle Kingdom.

I am truly an official of great heart,

a sweet lovable plant.

I was no drunkard, I was not forgetful;

I was not sluggish at my task.

It was my heart that furthered my rank,

it was my character that kept me in front. ${ }^{15}$

This new concept of the heart belongs to the discourse of the clients and not to that of the patrons. Great stress is laid on integration, subordination, "silence", self control, obedience and altruism (honesty, charity, fairness). The main evils to be resisted are greed, egotism, self-assertion, independence, violence, aggression, recklessness, passion, uncontrolled emotion, uninhibited self-indulgence. This seems clearly a reaction against the glaring individualism of the patrons such as Ankhtifi, the type of $s h m-j b$, the "powerful-of-heart". ${ }^{16}$

To this discourse belongs the emergence of a new type of autobiography which M. Lichtheim aptly calls "the moral profile". A typical example can be found in one of the stelae of a certain Antef (BM 572) of which I quote some verses:

Uniquely skillful, excellent of counsel, who heeds the word of those who know their speech, who is sent because deemed worthy, who gives account to the judge, knowing the turn of the heart's concern. Praised by his chiefs, known in the lord's house, whose heart conducts his affairs, who bends his arm to his superiors, who is beloved by the king's courtiers. A famed name as a knower of things, who follows the path without swerving, who hears the word in the chapel of Geb, privy to the secrets in the judgment hallthe honoured chamberlain Antef son of Sent. ${ }^{17}$

The most explicit elaboration, however, of this concept of the heart as inner self appears on the stela of another Antef who lived some

${ }^{15}$ Lichtheim Ancient Egyptian Autobiographies, Chiefly of the Middle Kingdom, Freiburg 1988, 42-46.

${ }^{16}$ Cf. G. Fecht, Der Vonerurf an Gott in den Mahnworten des Ipuwer, AHAW 1972, $136 f$.

17 Lichtheim Autobiographies, 107. 
four or five hundred years later under Thutmosis III and who followed in his autobiography closely the model of the Middle Kingdom:

It was my heart that induced me to do this, according to its instruction for me.

It is an excellent witness for me:

I did not violate its injunctions.

Because I feared to transgress its orders

I prospered exceedingly well.

I did very well because of its instructions concerning my way of action. I was free of reproach because of its guidance.

(...) It is a divine utterance in every body,

blessed be he whom it has conducted on the right way of action. ${ }^{18}$

The heart, in this concept, appears as a moral instance, giving orders and instructions which must not be "violated" and "transgressed". The voice of the heart is not the voice of self-reliant individuality but of social and moral responsibility which already has come to be recognized as a divine voice. It comes close to our notion of conscience, Gewissen. The voice of the heart is the interiorized voice of the community. It functions as common sense, in the latin sense of sensus communis. It is the organ by which the individual is open to the rules of togetherness and lets him/herself be bound and built into the structure of the community.

\section{III}

Let us now return to the point from where we started, the movement of Personal Piety and the emphasis it laid on the heart and its decision for God. It seems obvious that we are dealing here with the application of the patron-client-relationship to the god-man-relationship. In the Middle Kingdom, this model had been adopted by the state in order to re-define the pharao-subject-relationship. In the New Kingdom, the same model enters the sphere of political theology and religious anthropology.

This development has a very strong parallel in the Bible and its covenant theology. The covenant theology is nothing other than the application of another political model, the lord-vassal-relationship to the religious sphere. The relationship between JHWH and His

\footnotetext{
974f.

${ }^{18}$ Louvre C 26: K. Sethe, Urkunden des ägyptischen Altertums IV, repr. Graz 1961,
} 
people is modelled upon the relationship between an overlord such as the king of Assur and a vassal king. In Biblical religion, we are dealing with the relationship between god and a collective subject called Israel. In Egypt, we are dealing with the relation between a deity and an individual. In both cases, however, the political model is used to form a new religious relationship.

The new Egyptian concept of God as formed within the context of Personal Piety inherits the traditional roles and images of the patron. Like the patrons of the FIP and the pharaohs of the MK, God is called pilot and steering oar, father of the fatherless, husband of the widow, judge of the poor. The new ideal of the pious one, on the other hand, inherits the characteristics of the client, his virtues of humbleness, modesty, self-control and "silence" as well as his status as an orphan, a poor one, a pilgrim and a mendicant. All these are images describing the position of dependence into which the individual has placed himself. Also the situational context of the decision is similar. In the FIP we find strong descriptions of distress and disorder. In the New Kingdom we meet with problems of a more individual kind. People are turning to god in search of a shelter from fear and anxiety, guidance in a pathless and unintelligible world, protection against persecution, human injustice, malign demons and deities, dangers of all sort including the fear of Pharaoh. ${ }^{19}$ Typical requests for salvation refer to the injustice of the judges and to calumny: "may you rescue me from the mouth of men". ${ }^{20}$ Now not only man's inner world of passions, fears, drives and emotions but also the outer world of society and nature are considered unsteady, irrational, subject to abrupt change:

Do not say "Today is like tomorrow".

How will this end?

Comes tomorrow, today has vanished, the deep has become the water's edge.

Crocodiles are bared, hippopotami stranded, the fish crowded together.

Jackals are sated, birds are in feast, the fishnets have been drained. ${ }^{21}$

19 LÄ "Furcht"; "Gefährdungsbewußtsein".

${ }^{20}$ tBM 5656 ÄHG Nr. 190, 38-40 see p. 612 for other references. Cf. Job 5.21. Also the teaching of Amenemope promises to "save him (the disciple) from the mouth of strangers" (I.11), Lichtheim AEL II, 148.

${ }^{21}$ Amenemope 6.18-7.4; Lichtheim AEL II, 151. 
The world has become unintelligible, uncalculable and unstable. It no longer inspires comfort and confidence. There is nothing firm and stable within and without but god, the sole resting point in a turning world. In order to find steadiness, man has to put god into the heart, as the phrase goes, and to surrender to god's leadership. This idea finds its most explicit and as it were "classical" expression in a famous passage in the teaching of Amenemope:

Keep firm (dns "make heavy") your heart, steady your heart.

Do not steer with your tongue.

If a man's tongue is the boat's rudder, the Lord of All is yet its pilot. ${ }^{22}$

This is the point where piety differs from loyalism. No loyalist text has ever gone so far as to ask for placing the patron or the king into one's heart. The decision for a king or patron should be a matter of the inner self and not just a kind of lip-service. Now, with the transition from loyalism to piety, the idea of the heart-directed man turns into that of the god directed heart. This is what conversion means in the context of Personal Piety.

\section{AbBreviations}

AEL I, II M. Lichtheim, Ancient Egyptian Literature, Berkeley, I, 1973, $\begin{array}{ll}\text { ÄHG } & \text { II, } 1976 \\ \text { J. Assman, Ägyptische Hymnen und Gebete, Zürich, } 1975\end{array}$

FIP First Intermediate Period

LÄ Lexikon der Ägyptologie

LEM Late Egyptian Miscellanies

MK Middle Kingdom

NK New Kingdom

OK Old Kingdom

TUAT Otto Kaiser (ed.), Texte aus der Umwelt des Alten Testaments,

ZÄS Zütersloh $\quad$ Zeitschift für Ägptische Sprache

${ }^{22}$ Amenemope XX.3-6; Lichtheim AEL II, 158. 